\section{CONNECTIONS WITH PAULO FREIRE'S \\ CONNECTIONS WITH PAULO FREIRE'S
LEGACY IN ANTI-RACISM MEDIA ACTIVIST COLLABORATION IN FINLAND}

\section{Leonardo Custódio}

Åbo Akademi University (Turku, Finland)

ORCID: 0000-0002-7537-9671

leonardo.custodio@abo.fi

\section{CONEXIONES CON EL LEGADO DE PAULO FREIRE EN LA COLABORACIÓN MEDIACTIVISTA ANTIRRACISMO EN}

Para citar este artículo:

Custódio, L. \& Gathuo, M. (2020). Connections with Paulo Freire's legacy in anti-racism media activist collaboration in Finland. Commons. Revista de Comunicación y Ciudadanía Digital, 9(2), 133-158. http://doi.org/10.25267/COMMONS.2020.v9.i2.04

Fecha de recepción: 04/05/2020. Fecha de aceptación: 01/06/2020

\begin{abstract}
In this article, we introduce the Finland-based initiative Anti-Racism Media Activist Alliance (ARMA Alliance, 2018-2020). The article presents our ethical-methodological reflections about the processes of collaboration and dialogue we have experienced as co-founders and coordinators of ARMA Alliance. Our analysis is grounded on our joint retrospective analysis of how the activist-research purposes of ARMA Alliance connect with Paulo Freire's legacy. Our objective is to contribute to scholarship that problematizes the multi-layered relationship between research and activism in collaborative processes of communication for social change (in our case, against racism). First, we present what the ARMA Alliance initiative means and how it connects with Paulo Freire's work. Then, we look back at the decolonial insights, cathartic encounters and dialogues that led to the development of the initiative. After that, we reflect about the relationship between collaboration and conscientization. Lastly, we indicate some experiences in putting dialogue and collaboration into practice.
\end{abstract}

\section{Keywords}

Anti-racism, media activism, collaboration, conscientization, Finland

\section{Resumen}

En este artículo, presentamos la iniciativa Anti-Racism Media Activist Alliance (ARMA Alliance, 2018-2020), con sede en Finlandia. El artículo presenta nuestras reflexiones ético-metodológicas sobre los procesos de colaboración y diálogo que hemos experimentado como cofundadores y coordinadores de ARMA Alliance. Nuestro análisis se basa en nuestros trabajos retrospectivos conjuntos sobre el modo en el que los propósitos de investigación activista de ARMA Alliance se conectan con el legado de Paulo Freire. Nuestro objetivo es contribuir a los debates académicos que problematizan las múltiples relaciones entre la investigación y el activismo en procesos colaborativos de comunicación para el cambio social (en nuestro caso, contra el racismo). Primero, presentamos lo que significa la iniciativa ARMA Alliance y cómo se conecta con el trabajo de Paulo Freire. Luego, miramos hacia atrás a las ideas descoloniales, los encuentros catárticos y los diálogos que llevaron al desarrollo de la iniciativa. Después de eso, reflexionamos sobre la relación entre colaboración y concientización. Por último, indicamos algunas experiencias para poner en práctica el diálogo y la colaboración.

\section{Palabras clave}

Antirracismo, mediactivismo, colaboración, concientización, Finlandia 


\section{Anti-Racism Media Activist Alliance and Paulo Freire}

In this article, we - a Finn and a Brazilian, both Black in Finland - construct a joint, critical self-reflection about our experience promoting anti-racism collaboration as co-founders and coordinators of the Anti-Racism Media Activist Alliance (ARMA Alliance). In ethical-methodological terms, ARMA Alliance is an activist-research initiative (cf. Hale, 2008). That is, an initiative that combines research and activist methods to promote dialogue, collaboration and alliance with people engaged in anti-racism practices inside and outside the university.

The formation of ARMA Alliance illustrates this activist-research orientation. After meeting in a conference in 2017, Leonardo Custódio, as a postdoctoral researcher, and Monica Gathuo, a community organizer and, at the time, journalist at the Helsinki-based, women-led media collective Ruskeat Tytöt (RT, Brown Girls) started a conversation to develop collaboration that combined theory and practical experience of uses of media against racism. RT is the first media platform managed and produced by women of color in Finland. When they accepted the proposal for collaboration, Gathuo started working with Custódio to develop a plan for funding application. Later that year, we were awarded a three-year grant ${ }^{1}$ to develop ARMA Alliance. Months later, Gathuo left RT. Since then, ARMA Alliance has continued as an initiative on its own that collaborates with multiple anti-racist actors in Finland which directly or indirectly engage with media activism against racism.

We define anti-racism media activism as creative uses of media technologies (e.g. cameras, recorders, computers, mobile phones, printers) and online/offline platforms (e.g. printed materials, broadcasting channels, social media, mobile applications) for audiovisual, textual, artistic and journalistic initiatives that directly or indirectly contribute to struggles against racism (cf. Pickard \& Yang, 2017; Custódio, 2017). With this general understanding of anti-racism media activism in mind, we summarized our activist-research objectives into one question: What can we learn by doing research about and acting together with anti-racism media activism by people who suffer from racism?

1. ARMA Alliance started thanks to the financial support by Kone Foundation (2018-2020). 
To seek for answers, we have engaged with activists of racially marginalized social groups in Finland (e.g. Black, Brown, Romani, Sámi) who use media activist tactics to act for change. In addition to Ruskeat Tytöt, some of the initiatives by people in social groups that suffer from racism with which we collaborate in Finland include: Good Hair Day (GHD Helsinki), which promotes Black awareness through public discussions (online and face-to-face) around beauty and Afro-Finnish aesthetics; Anti-Racist Forum (ARF), which promotes anti-racism education workshops and uses social media to mobilize anti-racist action; Femma Planning, a participatory urban planning initiative that produces a podcast which debates issues of discrimination and racism in urban design; the writer and public figure Maryan Abdulkarim and others.

Our activities as ARMA Alliance combine theoretical knowledge with practical activist experience to study, develop and promote multiple aspects of anti-racism media activism. We follow three key principles: knowledge exchange, creative publishing and international networking. With these principles in mind, we have organized public events, conference panels, film screenings and other activities to both bring scholars and activists together in dialogue. These gathering and dialogues have led to the production of texts and audiovisual materials that promote further conversations about how communication can provide powerful tools, platforms and processes to denounce, resist and dismantle racism.

Conceptually, we consider anti-racism media activist initiatives to be pieces of complex and dynamic sociopolitical processes. Communication, in its broadest sense, is among the most fundamental symbolical element for human beings to exist as societies. After all, social life results from a continuum of interactions, knowledge production, circulation of shared meanings and conflicts. Take "racism" as an example. Fundamentally, racism is a social, cultural and political process in which people - intentionally or not - use the idea of race to define certain groups of people as inferior (Kendi, 2016; Saini, 2019). Therefore, anti-racism media activism by people who suffer from racism is important for two reasons related to Paulo Freire's legacy: It re-signifies symbols, attitudes and arguments that have historically caused damage, pain and death to social groups racialized 
as something else than the dominant group in different societies. In addition, it brings individuals together to exchange knowledge and act together to change society (cf. Kendi, 2019; Titley, 2019).

Approaches to media by marginalized people has a tradition of its own in the field of communication for social change (Gumucio-Dagron \& Tufte, 2006), but arguably anti-racism media activism has not been studied much from an international perspective in communication studies (Titley, 2019: 183). In addition, we believe that being Black grants us an opportunity to analyze the character of local actions by people like us who speak up and act against racism in Finland and elsewhere (cf. Custódio, 2016). We do so without ignoring — and actually problematizingthe fact that while being Black makes of us insiders of the social group in which we are interested (namely "people who suffer from racism who engage in media activism"), we are also to some extent outsiders due to our positions in the university (Custódio as a postdoctoral researcher, Gathuo as an MA student) and the role we play as observing researchers (see Custódio, 2017).

How does our work at ARMA Alliance relate to the legacy of Paulo Freire? This question, that underlies the writing of this article, became a point of reflection after Custódio participated in the Brazil Seminar at the Loughborough University London in June 2019. As an educator committed to promoting critical thinking and political awareness through adult education among low-income rural workers in highly unequal Brazil, Paulo Freire's theoretical-philosophical legacy (Mayo, 2008 ) is of great importance for anyone engaged in activist research.

In our development process of ARMA Alliance, we did not invoke the work of Paulo Freire as a formal reference. Nevertheless, many of the elements of Freire's work were and remain present in our thinking both as researchers and activists: the importance of communication as dialogue for social change, the power relationships between the (racially) oppressing and oppressed, the importance of sharing knowledge as a process of mutual education and conscientization, and the urgency of engaging theory with the construction of socially transformative practices. In this article, then, we make an ethical-methodological self-critical 
reflection about collaboration and dialogue in ARMA Alliance in a kind of retrospective effort to identify and make more explicit connections of our work with Freire's legacy.

\section{Decolonial insights, cathartic encounters and dialogue: the making of ARMA Alliance}

Let us start from the beginning and reflect upon (a) what insights and encounters inspired the construction of ARMA Alliance and (b) how Paulo Freire's understanding of the relationship between oppressor and oppressed (Freire, 2000 ) relates to this process. Fundamentally, in Freirean terms, it is unlikely that we would have developed ARMA Alliance if we were not Black - a social group historically oppressed by racism in societies of dominant whiteness-. By whiteness we refer to the sociopolitical and cultural consequences of the historical diffusion (through colonization, imperialism and capitalism) of Western and Northern European physical appearance, values and traditions as normalized standards and superior forms of beauty, intelligence, culture, politics, economy and other social constructs constitutive of social life (Yancy, 2017; Keskinen, 2018; Loftsdóttir \& Jensen, 2016).

Freire originally thought of oppression as a consequence of class-based discrimination in unequal Latin America (Freire, 2000). In such contexts, racism (as well as xenophobia, sexism and homophobia) also shapes patterns of inequality and discrimination. As Black people, we know from an early age that in societies where whiteness is a norm, racial oppression translates as various forms of discrimination and violence against people who have historically been racialized as inferior and dangerous. Not only do class, race, ethnicity and gender intersect, they also add up. For instance, if one is poor, the more traces of Blackness one has, the more one is likely to suffer from racism. It is worse if the person is female. Even worse if the person is transsexual. Moreover, racism does not disappear if a Black person ascends socially. Patterns of racial oppression change if/when one is economically stable. Therefore, Black people like us (and other social groups racialized as non-white) will always have to deal with others -intentional or 
unintentional, violent or well-meaning - attitudes shaped by the idea of racial hierarchy naturalized through history in societies of predominant whiteness. Be it an unequal country like Brazil or a welfare state like Finland.

In addition to how racism affected our lives as Black people, the earliest ideas for the construction of ARMA Alliance also came from what we could refer to as "decolonial insights". By "decolonial" we refer to the constant effort to identify, deconstruct and re-signify aspects in thinking, language and practices that have historically been shaped by colonization and coloniality. By coloniality we refer to the conceptual construct that sheds light on the material and symbolic consequences of colonialism in social life (Quijano, 2007; Mignolo \& Escobar, 2010; Mignolo, 2011). The Puerto Rican scholar Nelson Maldonado-Torres (2007) developed a definition for coloniality that is very important for its clarity:

[Coloniality] refers to long-standing patterns of power that emerged as a result of colonialism, but that defines culture, labor, intersubjective relations, and knowledge production well beyond the strict limits of colonial administrations. Thus, coloniality survives colonialism. It is maintained alive in books, in the criteria for academic performance, in cultural patterns, in common sense, in the self-image of peoples, in aspiration of self, and so many other aspects of our modern experience. In a way, as modern subjects we breathe coloniality all the time and every day. (Maldonado-Torres, 2007: 243)

In this sense, to decolonize designates both the historical movements to rip countries apart from colonial rule and the intellectual action to dismantle coloniality during and after colonialism (Mignolo \& Escobar, 2010; Cusicanqui, 2012; Tuck \& Yang, 2012; Bhambra, 2014). That is, actions deemed as decolonial target four interrelated dimensions of the colonial matrix of power as defined by Walter Mignolo: the historical and systematic management and control of subjectivities, authority, economy, and knowledge. Racism and patriarchy underlie the production of knowledge in this matrix (Mignolo, 2011).

The systemic nature of coloniality serves as a historical framework for ARMA Alliance as an anti-racist, activist-research initiative. Coloniality impacts the lives of people like us, who have descended from the native and the enslaved. In our 
case, when we talk about "decolonial", we refer to coloniality as an element of everyday life rather than a national-historical character. Finland - where we live and work - does not have a colonizing past despite having benefited in complicity and applied colonial patterns of territorial control against its native people (Keskinen, 2018; Loftsdóttir \& Jensen, 2016). However, the prefix Afroattached to our nationalities and the ways racism haunts us because of our roots and skin indicate that our biographies are permanently stamped with coloniality independently of where we live. This means, to be sure, that we embody, suffer from and deal with coloniality. In that sense, our trajectories as Afro-Brazilian and Afro-Finnish in the university and in activism represent individual searches of continuous opportunities to learn, understand and act against racism and the oppressing elements of whiteness that have affected us throughout our lives.

Gathuo has been involved with activism and journalism since 2012. While pursuing her bachelor's degree in Glasgow, Scotland, she participated in local film festival productions and discovered the power that films and film festivals have as tools of activism. In 2015, after finishing her studies, Gathuo returned to Finland. In search for similar events and activist communities, she found the Helsinki African Film Festival. By being part of the production team, Gathuo found more means to participate in the local activist scene and gave her knowledge on community organizing. When she joined Ruskeat Tytöt (Brown Girls) media, Gathuo focused more on the community of people of color (PoC) in Helsinki and its activists. By observing the community, Gathuo became acquainted with Black activist culture and critical reading ${ }^{2}$. Custódio gradually familiarized with online media by racially marginalized people in Brazil and in Finland while conducting his research on media activism in favelas of Rio de Janeiro (Custódio, 2017). Websites such as Blogueiras Negras (Black Female Bloggers, Brazil) and Ruskeat Tytöt (Brown Girls, Finland) similarly raised discussions that contested Western beauty standards, denounced of racism, and promoted community-building efforts online and offline.

2. Gathuo is especially thankful to active members such as Efe Ogbeide and Maija Baijukya, who introduced her to initiatives and texts on Black activism. 
In hindsight, our trajectories into becoming agents in anti-racism struggles suggest another connection to Freire's legacy: the importance of communication as dialogue as an element for individual transformation through collective action and social change (Freire, 2013b). As members of the university community in Europe, we have been on the privileged side of the social spectrum in cultural and economic terms. In that sense, Freire's original understanding of being oppressed in terms of class has not applied to us. Despite that, it was only after accessing media materials and experiencing dialogue with peers already engaged in anti-racism struggles that we realized how racism has affected us and how the suffering of peers also concerns our existence. Only then did we start participating in individual and collective activities against racism that includes, among other elements, the need to learn and share knowledge in processes of dialogical communication and solidarity.

Such drive to learn together and share knowledge paved the way for us to meet for the first time in 2017 at the Afroeuropeans Conference in Tampere, Finland. Meeting there was a cathartic dialogical experience, which was crucial for the construction of ARMA Alliance. It was cathartic because of how we both felt anguish and other unsettling feelings as Black people in individual processes of learning and politization regarding racism in contexts of predominant whiteness. Having had been personally interested in issues of identity and anti-blackness for the personal experience of being a Black Finnish person who felt she did not belong, Gathuo decided to volunteer and participate in the conference after she had learned about it through friends. To learn more about issues of racism, Custódio joined the organization team. He also presented a paper proposing a comparative approach to anti-racism media activism in Finland and Brazil by demonstrating how the Brazilian website Blogueiras Negras (Black Female Bloggers) and the Finnish website Ruskeat Tytöt (Brown Girls) shared similarities despite the differences between their contexts of action.

After attending Custódio's presentation, Gathuo and other Afro-Finns approached him. From that conversation, an idea for collaboration between anti-racism research and activist came up, leading to the planning, funding application and award as previously described. From then on, the insights and the cathartic 
encounters have led to what we consider decolonial collaborative practices with peer Black people, with racialized people of other social groups, and white people. These activities - sometimes promoted by us as ARMA Alliance, other times promoted by other collective actors - aim at generating continuous processes of knowledge sharing through dialogue (Freire, 2013b). By doing so, we engage in dialogic action not only to educate ourselves as people who suffer from racism, but also to share information about the aspect of anti-racism action we know best by life experience and education: the importance of communication and media activism for the struggles against racism.

As an initiative that combines activist and research methods, we think ARMA Alliance as a longitudinal multi-method process. Our first methodological step was to apply qualitative interviews (Klandermans \& Staggenborg, 2002). We had two main objectives: to gather materials for analysis and map anti-racist activist practices. In the spring of 2018, we started our planned interviews in Finland $(n=30)$. In the autumn, we conducted them in Brazil $(n=30)$. Even though the core of our work is in Finland, the interviews in Brazil have served both to establish collaborative connections and to have material with which to compare antiracism media activist practices that happen in societies with different histories and societal characteristics from one another. In Brazil we interviewed people who identify as Black (due to geographic restrictions, we were not able to interview indigenous people). In Finland, interviewees included Black (of East African and Sub-Saharan heritage), Romani, Sámi, and Brown (of South-Asian and Middle Eastern heritage). One criterium for the selection of interviewees in both countries was that the activists engaged in media and communication practices in their repertoires.

As the initial phase of ARMA Alliance as a multi-method process, the interviews proved inspiring and enlightening. As an activist process, the fact of sharing the experience of racism created an atmosphere of affinity and empathy between us and the interviewees. In research terms, the interview process gave us food for thought about how our admiration and commitment to the anti-racist cause could affect the scientific value of our analysis. The nuances of doing research about 
a community to which we belong (for being Black), but also do not belong (for being researchers) is something we have both problematized in our own writings elsewhere (Gathuo, 2019; Custódio, 2017).

In addition to interviews, we have acted to bring research and anti-racism activism into dialogue. In methodological terms, we have used academic platforms for dialogical encounters (e.g. conferences) and networking towards the promotion of collaboration. In 2019, for instance, we organized a panel at the 2019 Afroeuropeans Conference in Lisbon. In the conference, we brought together scholars and activists from Brazil, Portugal, Finland, Germany, the USA and the UK. In 2020, we organized a panel in the Development Conference of the Finnish Society for Development Research, in Helsinki. For this panel, we brought together researchers and activists based in Finland from and with roots in Asia, Africa and Latin America. In both cases, our goal was to use the structure of academic gatherings to facilitate dialogue between anti-racism activists and researchers. The combination of scientific and activist knowledge with the experiences resisting racism in different societies has indicated the epistemological relevance of an international, comparative approach to anti-racism media activism and the political importance of building bridges between people acting collectively against racism around the world.

We have also promoted dialogue and opportunities for collaboration outside academic settings. In Finland, we created the series of open conversations called "ARMA Talks". In these events, we mediate conversations between people who suffer from racism who are somehow active in media activist initiatives that directly or indirectly contribute to anti-racism struggles. In these events, we also include dialogue between international media practitioners, activists and academics. For each "ARMA Talks", we develop the questions taking into consideration the intersections between theory and public debates about media, racism and media activism in different societies. In 2019, for example, we organized the panel "Black Women's Voices in Times of Hate" in Helsinki. The conversation, organized in partnership with colleagues at the University of Helsinki, featured Maryan Abdulkarim, Finland's prominent Black and Muslim writer, and Silvana Bahia, one of Brazil's leading Black female voices in technology innovation and communication. 


\section{Collaboration and Conscientization}

In addition to promoting dialogue and learning, the activities of ARMA Alliance in academia and beyond represent our pursuit to engage in collaborative processes for the sake of what Freire refers to as "conscientization". "Collaboration" is a word that is constantly invoked in the context of politically engaged research, activism and arts in Finland. Due to the low-budget, minimum-resource condition that affects most people in these areas, collaboration becomes a means to engage in theoretical, artistic and civic action (cf. Wang \& Soule, 2012). In common sense, we often understand collaboration as the process of working together with someone to produce something while sharing costs, responsibilities and tasks so to benefit all parties involved - collectively and individually- while also generating something new that can potentially change aspects of social life.

As we have indicated so far, ARMA Alliance is a duo, not a network of organizations. This means that, as ARMA Alliance, we create activities in collaboration with individuals and initiatives engaged in anti-racism media activism. For example, in Helsinki, we often collaborate with the Community for Urban Culture, Art and Events, also known as UrbanApa. Every year, UrbanApa organizes the anti-racist event \#StopHatredNow to promote inclusivity, diversity, accessibility and socialecological sustainability ${ }^{3}$. In practice, our collaboration with UrbanApa includes the organization of public talks and open lectures in which we discuss anti-racism media activism. They organize the event. We organize and cover all the costs of our own activities within their program. For UrbanApa, our contribution adds up to the diversity and reach of their event. For us, \#StopHatredNow is an important platform to diversify and increase the reach of our work. Most importantly, by collaborating with UrbanApa we share what we know and learn from other collaborating sociopolitical actors.

3. Read about the 2020 \#StopHatredNow event here: http://urbanapa.fi/event/stophatrednow-2020/ 
In other words, our understanding of collaboration lies in building productive relationships for the sharing knowledge and resources between researchers and activists. Derickson and Routledge (2015) work with the notion of "resourcefulness" as a guiding framework for what they refer to as "scholaractivism" engaged in processes of co-production of knowledge "with and for our community-based collaborators" (2015: 1). They argue that resourcefulness is a useful notion in three ways: how scholars can commit resources and privileges with nonacademic collaborators, how research design can be developed to cater to what collaborators want to know, and to explore limitations nonacademic collaborators face in their participation in research and their activism. They also suggest scholar-activism to acknowledge power disparities, respect the power and knowledge of nonacademic collaborators and thus adopt an approach "built on mutual trust, admiration, and benefit" (Derickson \& Routledge, 2015: 5). In addition, it is important to emphasize that such relationships should not deny difference and conflict as an important part of collective action for social change (Ganesh \& Zoller, 2012).

In our case, by thinking in terms of resourcefulness, we can acknowledge our sources of power (e.g. ARMA Alliance's three-year financial grant) and our limitations (e.g. being only two people). By recognizing differences, we can develop more fair and inclusive forms of collaboration. This is especially important for us because we suffer from and act against racism just like most people with whom we collaborate do. That is why we embrace political positioning instead of performing the pretense of neutrality. That is also why, as Black people pursuing academic careers in Finland, we believe that collaborative initiatives combining activism and research should aim at constant self-reflection, dialogue, codeciding, and shared responsibilities throughout the process so that the results ultimately benefit the communities that suffer from and act against racism.

Freire's understanding of praxis as action and reflection to transform the world (Freire, 2000) is the essence of our principle of knowledge exchange. In our collaboration with UrbanApa and other initiatives in Finland, for example, we pursue the belief that by organizing public conversations (action) whose 
discussions are grounded on theoretical debates (reflection), we are contributing to raising the issue of racism in a predominantly white society. Public conversations on anti-racism media activism for us are, in Freire's terms, dialogical. For Freire, dialogue is a process of both learning and knowing shaped by epistemological curiosity, deep self-reflection about one's own relationship with the world and the individual and collective conflicts that arise from directly confronting inequalities and learning how to act against them (Freire \& Macedo, 1995). For example, the first public conversation we organized in collaboration with UrbanApa in 2018 was a panel about on what media activism means in practice for people racialized as nonwhite in Finland. The participants were a filmmaker (Romani heritage), a cartoonist (Somali heritage) and an artist/online personality (West African heritage).

Another Freirean principle in our work is that of conscientization conscientização-. In short, conscientization regards the process in which people develop critical awareness both about the reality in which they live and their capacity to change realities through action (Freire, 2000). Here, raising critical awareness and changing one's own reality translates as steps towards freedom in Freirean terms. In the Brazilian and Latin American contexts in which he originally taught and wrote in the 1960s and 1970s, freedom through conscientization meant understanding and acting against the domination of land-owning, militarysupported economic elites over rural workers not only in terms of their bodies for labor, but their minds for adhesion to an oppressing system of exploitation in which illiteracy and "banking education", at the time, were powerful tools for mass control (Freire, 1998). In our view, conscientization towards an anti-racist praxis in today's neoliberal world means identifying how whiteness still maintains its racist logic of institutional/structural oppression in a world where market economy and logics prevail over social justice and welfare. Our own learning processes towards becoming engaged in anti-racism struggles, as described previously, can be considered examples of conscientization.

By engaging in processes of collaboration for conscientization as Black people in privileged positions due to our class and income status, we have to be self-critical about our position even if we also suffer from racial oppression. That means following Freire's example of acknowledging and positioning critically concerning 
the power differences and the hierarchies shaping the relationship between him as a middle-class progressive educator and the low-income students (Freire, 2013). Like Freire's, our position requires constant vigilant self-reflection not to reproduce exploiting and discriminatory patterns of racism. We, as highly educated and, for the moment, financially stable Black people experience less explicit forms of individual and institutional racism in Finland than our undereducated and precariously employed peers. Yet, we all share a history of psychological, social, political and economic effects of the sickening lifetime experience with, in and under Western whiteness.

In processes of conscientization, mutuality is fundamental. In ARMA Alliance's activities, researchers bring in what they/we have learned in the institutional spaces of education. Activists bring in their expertise and knowledge built in their experiences inside and outside formal institutions of education. Together, these sets of knowledge contribute to our common struggle against racism despite all the differences and conflicts that may exist among us. In this sense, speaking in terms of conscientization is both an acknowledgement to our dual character as people who teach and learn, and also a reminder of the role we play in a global history of anti-racism action and resistance that precedes and will follow all of us.

\section{Different forms of collaboration for conscientization}

We would like to conclude this article by reflecting on some practical aspects of collaboration as types of activist-research anti-racist praxis (cf. Freire, 2000) in which we have engaged. Some of our collaborative experiences in the making of ARMA Alliance can illustrate how collaborative practices can be very challenging, but also enriching processes. At ARMA Alliance, we have conducted at least three types of collaboration: (a) between ourselves, (b) with members of the community of people racialized as non-white, and (c) with people racialized as white. In describing these three instances of collaboration, we hope to demonstrate how the preparation and the conduction of these processes resemble Freire's understanding of mutual learning. 


\section{1. Collaboration between ourselves in ARMA Alliance}

The interview process is the most suitable illustration to our understanding of collaboration in the making of ARMA Alliance. From our very early planning, we agreed that talking to people was the best way to familiarize ourselves with antiracism media activism initiatives. For our collaborative interviewing process, the first step was to develop the interview guide. That is, a list of open-ended questions organized by themes so that interviewees can elaborate ideas freely within thematic constraints. We were three people involved in the interview process: Gathuo in Finland, Custódio in Finland and Brazil, and Andiara Pereira -a Black LGBTQ activist researcher - in Brazil. Each of us included themes and questions so that the interview guide would combine our individual interests. The interview guide, after this collective production, looked as such:

Theme: Trajectory.

Questions: How do you identify yourself in terms of gender and race/ethnicity? When and how did you start doing what you do? Why and how did you decide to do what you do with/in/ through media?

Theme: Media practice.

Questions: How would you describe what you do? What technologies and media platforms online or offline- do you use? What are your objectives in doing what you do? Who are your target groups? What is your routine creating what you do? What motivates you to continue doing what you do? What disappoints you? What would you change?

Theme: Publics.

Questions: How do you think what you do reaches people in the social group with whom you racially/ethnically identify? What are the difficulties for you to reach people in the group with whom you identify? What kind of reaction does your work usually get? How do you feel about the reactions? 
Theme: racism, anti-racism and activism.

Questions: What is "activism" for you? Do you consider yourself and what you do to be "activist"? Why(not)? What do you consider yourself and your work to be? How has "racism" affected your life and your work? What would you think if someone described your work as "anti-racism activism"?

Theme: digital media.

Questions: What's the importance of digital media for what you do? If you could choose, would you do what you do in mainstream media? Why (not)? For what you do, what are the differences between mainstream media and digital media? What do you think about anonymity by and for people who make media related to issues of race and racism? How often have you considered acting or in fact acted anonymously? Why?

Theme: Networks/Mutual support.

Questions: What PoC initiatives (local or international) do you follow online and/or offline? Why do you follow them? How do you evaluate the presence of PoC people in mainstream media? Do you think it should change? Why (not)? How do you think what you and others do contribute to changing the society where you live?

Theme: Strategies.

Questions: Do you create different content for different online platforms? How do the formats for different platforms interfere in the type of content you produce? Do you create any type of strategy to distribute your content on social media? What strategies? Do you believe these strategies contribute to the anti-racist struggle? How?

Theme: Branding.

Questions: What do you think about the relationship between activism and big companies? Do you believe that a Black/PoC person that produces in partnership with brands is doing activism? 
Theme: Intersectionality.

Question: How do you evaluate the interference of different identity markers (e.g. gender, sexuality, class, body type, territory, etc) in your activist production?

With the guide drafted together, the second aspect of collaborative interviewing was to conduct the interviews in pairs. By conducting the interviews together, our goal was to have the simultaneous assessment of researcher and activist of the interviewee's answers. Due to time restrictions, we were only partially successful with our joint interview plan. In both countries, some interviews had to be conducted individually. Despite the challenges in implementation, the dialogue between different ages, genders and academic experiences in the interview process created an important process of knowledge exchange. In a certain way, each of us represented gates to one another to different aspects of anti-racism media activism: Custódio brought in activist knowledge and its application of critical media studies; Gathuo raised issues of positionality and self-perception in diverse PoC communities; and Pereira raised questions on the intersections between activism and neoliberalism from a queer perspective.

\subsection{Collaboration with the Community of Racially Marginalized People}

Our idea of collaboration with people in the community to which we belong directly relates to organizing events together and sharing ARMA Alliance resources. One concern we have is not to reproduce patterns of exploitation as we organize activities. This, in practice, has two meanings: (a) all parts involved in the collaboration must benefit from the results of the activities, and (b) people will get properly paid for their intellectual and practical expertise if they participate in activities that primarily enrich ARMA Alliance's portfolio. Here we do not refer to the unethical practice of paying for research interviews, but collaborative initiatives in which researchers and activists include their labor to produce something together in collaboration. 
Raising the issue of "money" and fair payment is a political statement. Often people racialized as non-white get invited to supposedly collaborative initiatives in which organizers benefit - financially or symbolically - from their presence, but their labor is not compensated. Instead, they are promised vague and ephemeral benefits such as "visibility to their work" and "connections with other stakeholders". In addition to not getting paid, another problem in these types of exploitative professional relationships is that the creative production of people racialized as non-white has a great risk of being appropriated or stolen if they speak publicly about their raw and unpublished ideas. These are structural problems that we cannot fix in the scope of ARMA Alliance. However, we believe we are in a position to promote and advocate for genuinely collaborative practices with people in our own communities.

The issue of fair payment is important to highlight how collaboration with peers is not free of challenges. Such collaborative initiatives form a constant process of self-reflection to prevent reproducing the logics of exploitation. When are we collaborating with peers instead of including them as participants in ARMA Alliance's activities? Take our collaboration with UrbanApa once again as an example. It took us some internal discussion about whether to pay the guests and how much. It is easier than one assumes to slip into a certain exploitative demand from peers to work and/or appear as guests for free because "it is for a common cause". The matter of fact is that art, culture and activism are very precarious areas of action especially for people racialized as non-white in societies of predominant whiteness. The racial inequality in this precarious condition needs to be taken into consideration when we - especially those of us with funding, like ARMA Alliance - want to engage in collaboration with peers racialized as non-white for our common struggle against racism.

\subsection{Collaboration with people racialized as white}

To some extent, the reasoning behind our collaboration with peers racialized as non-white reflect on our collaborative relationships with people racialized as white. However, instead of us engaging in another deep process of self-reflection, 
we expect that potential white partners go through an in-depth evaluation of how they can contribute to anti-racist struggles. Here, to be sure, we are not talking about "white" as phenotype, but the social, historical, cultural and political types of power attached to whiteness in Finland and elsewhere. Many white people are aware of the power of their whiteness and act in allyship and solidarity with people who suffer from racism. However, because of this generalized obliviousness to the oppressing nature of whiteness, many people racialized as white - especially in well-meaning progressive groups - recoil into defensiveness, engage in self-pity or react in aggressivity when called out to be more critical about their roles in actions against racism.

In that sense, we acknowledge that our role in collaborating with people racialized as white is in part pedagogical. Custódio, for example, has used the framework of ARMA Alliance to partner with predominantly white faculties and organize lecture courses that promote (self-)critical assessments among students of whiteness in media production, journalism and their own lives. Two of these lecture courses include "Media, Race and Society" (Tampere University, 2019) and "Communication and Social Change" (University of Turku, 2019). A more straightforward form of collaboration in the courses was involving speakers racialized as white and non-white. For the future, our goal is to include collaboration to the level of lecture course planning because we believe such courses create frameworks for collaborative action against racism in educational institutions.

However, in addition to pedagogical efforts, our collaboration with people racialized as white has also included partnerships in which institutional power is shared to facilitate the promotion of initiatives. The previously mentioned public roundtable "Black women's voices in times of hate" at Tiedekulma in the University of Helsinki. In that event, Gathuo mediated a conversation between writer and activist Maryan Abdulkarim and Brazilian NGO director, filmmaker and technology activist Silvana Bahia. Tiedekulma is one of the most suitable spaces for public conversations in Finland. For that reason, it is also very difficult to book and expensive to afford if one is not a staff member of the university. The factor allowed the event to happen was the collaboration with Docent Marjaana Jauhola, who used her institutional power to book the space. Jauhola also secured the 
payment for translation. This example illustrates how people racialized as white in stable institutional positions can contribute to anti-racist struggles: by using their power to create possibilities for people racialized as non-white to occupy legitimized spaces of knowledge production and dissemination.

\section{Closing words}

This article represents a journey towards identifying connections between the collaborative initiative we coordinate -Anti-Racism Media Activist Allianceand the legacy of Paulo Freire. In the previous sections, we tried to demonstrate how Freire's ideas on communication as dialogue, mutual learning, theory-andaction praxis and collaboration remain fundamental for the formation of collective action towards solidarity, conscientization, justice and progressive social change. Observers with a positivist mindset eager to measure collective actions by their societal impact could question the relevance of our actions. In essence, what we do is listen to and learn from people who act, promote encounters and conversations, and work to put out materials that contribute to creating visibility to anti-racism media activist actors and initiatives (an aspect of our work we intend to discuss in another publication). More often than not, we are confronted with the question: what difference do these actions make?

We would argue that what Freire defines as "conscientization" is the difference that generated actions that cause changes. As we reworked this article according to the comments we received from blind peer-reviewers, another \#BlackLivesMatter wave spread all over the world following the brutal killing of George Floyd by police officers in the United States. Essentially, the mobilizing nature of the \#BlackLivesMatter movement is what we define as anti-racism media activism. On the surface, people use social media to raise their voices, mobilize support and call for multiple forms of actions not only against one specific case of racism, but also against systemic and structural forms of racism. More importantly, even 
though \#BlackLivesMatter originally concerns the specific context of the United States, it has gradually been appropriated by people who act against anti-Black and other forms of racism elsewhere.

Here in Finland, the use of the hashtag not only represented acts of solidarity to the US movement, but also a platform to denounce racism as it manifests itself in the country. One initiative was particularly illustrative of what we have self-critically analyzed in this article. Following up the international rise of solidarity against anti-Black racism in the United States, two young women racialized as non-white in Finland put up an event on social media calling for a protest in solidarity with \#BlackLivesMatter on Helsinki's Senate Square. Due to the covid-19 pandemic, there were health concerns and doubts about the turn-up of protesters. On June 3 rd, 2020, for everyone surprise, between 3.000 and 4.000 people came together to demonstrate against racism. There, anti-racism activists of different ages and social groups -including some with whom we have collaborated as ARMA Alliance- spoke about racism in Finland and the importance of anti-racism work. The protest resembled a mass conversation for mutual learning, brought together through collaboration, that made a huge contribution to the public conscientization. Not only did we identify Freire's connections with our work, but also realized how relevant his lessons remain for the formation of collective actions against racial and other forms of oppression.

In these circumstances, (re)writing this article together has represented an important part of our collaborative journey. The process has enhanced our capacity of looking back at our actions and of reassessing of our original plans and the definition of our next steps as co-founders and coordinators of the AntiRacism Media Activist Alliance. The identification of the relationship between our actions with Paulo Freire's legacy has allowed us to reflect on what we fundamentally want to achieve by working in collaboration with one another, with peers who are racialized as non-white, and people racialized as white.

As it may be implicit in the previous pages, collaboration is not simply a way of working together against racism, but also an objective in itself. Developing different forms of collaboration is one of the most effective ways of putting anti- 
racism ideals into practice. However, we also need to constantly remember and remind ourselves that collaborating is not just an effort to work together, but also to recognize privileges, identify hierarchies and, with all that in mind, act above all in full respect to those with whom we collaborate. Achieving mutual respect and pursuing conscientization, as Paulo Freire has taught us, is one of those issues that requires constant vigilance, self-reflection and critical action so that coming together for change effectively produces transforming results. As ARMA Alliance, one important lesson we take from writing together is that Freire should not be only a faint influence in collaborative work (as it was in our case), but a central reference with which to engage in our efforts to promote mutual learning and solidarity for change. 


\section{Bibliography}

- BHAMBRA, G. K. (2014). Connected sociologies. London: Bloomsbury.

- CUSICANQUI, S. R. (2012). Ch'ixinakax utxiwa: A Reflection on the Practices and Discourses of Decolonization. South Atlantic Quarterly, 111(1), 95-109. doi: 10.1215/00382876-1472612

- CUSTÓdIO, L. (2016). Global overview of community media as peripheral political action (in Portuguese). Revista Mídia e Cotidiano, 10(10), 138-157. doi: https://doi.org/10.22409/ppgmc.v10i10.9799

- CUSTÓDIO, L. (2017). Favela media activism: Counterpublics for human rights in Brazil. Lanham: Lexington Books.

- DERICKSON, K. \& ROUTLEDGE, P. (2015). Resourcing Scholar-Activism: Collaboration, Transformation, and the Production of Knowledge. The Professional Geographer, 67(1), 1-7. doi: 10.1080/00330124.2014.883958

- FREIRE, P. (1998). Reprint: Cultural Action for Freedom. Harvard Educational Review, 68(4), 471-521. doi: https://doi.org/10.17763/ haer.68.4.656ku47213445042

- FREIRE, P. (2000). Pedagogy of the oppressed (30th anniversary edition). New York: Continuum.

- FREIRE, P. (2013a). Pedagogia da esperança: Um reencontro com a pedagogia do oprimido. Rio de Janeiro: Paz e Terra.

- FREIRE, P. (2013b). Extensão ou comunicação?. São Paulo: Paz e Terra.

- FREIRE, P. \& MACEDO, D. (1995). A Dialogue: Culture, Language, and Race. Harvard Educational Review, 65(3), 377-402. doi: https://doi.org/10.17763/ haer.65.3.12g1923330p1xhj8

- GANESH, S. \& ZOLLER, H. (2012). Dialogue, Activism, and Democratic Social Change. Communication Theory, 22(1), 66-91. doi: 10.1111/j.14682885.2011.01396.x 
- GATHUO, M. (2019). The inside outsider: The effects and self-reflections of researching one's own community. In A. KYNSILEHTO, S. PELLANDER \& E. PUUMALA (Orgs. Committee). 16th ETMU Conference 2019: Solidarity, participation, and politics. Solidarities in Politically Engaged Research: Ethical and Methodological Challenges and Innovative Practices. Tampere University, Finland.

- GUMUCiO DAGRON, A. \& TUFTE, T. (Eds). (2006). Communication for Social Change Anthology: Historical and Contemporary Readings. South Orange (N.J.): Communication for Social Change Consortium.

- HALE, C. (Ed.). (2008). Engaging contradictions: Theory, politics, and methods of activist scholarship. Berkeley: University of California Press.

- KENDI, I. X. (2016). Stamped from the beginning: The definitive history of racist ideas in America. New York: Nation Books.

- KENDI, I. X. (2019). How to be an anti-racist. London: Penguin Random House.

- KESKINEN, S. P. (2018). The 'Crisis' of White Hegemony, Neonationalist Femininities and Antiracist Feminism. Women's Studies International Forum, 68(May-June), 157-163. doi: https://doi.org/10.1016/j.wsif.2017.11.001

- KLANDERMANS, B. \& STAGGENBORG, S. (2002). Methods of social movement research. Minneapolis: University of Minnesota Press.

- LOFTSDÓTTIR, K. \& JENSEN, L. (Eds). (2016). Whiteness and postcolonialism in the Nordic Region: Exceptionalism, migrant others and national identities. Farnham: Ashgate.

- MALDONADO-TORRES, N. (2007). On the coloniality of being. Cultural Studies, 21(2-3), 240-270. doi: 10.1080/09502380601162548

- MAYO, P. (2008). Liberating praxis: Paulo Freire's legacy for radical education and politics. Rotterdam: Sense.

- Mignol0, W. (2011). The darker side of Western modernity: Global futures, decolonial options. Durham: Duke University Press. 
- MIGNOLO, W. \& ESCOBAR, A. (2010). Globalization and the decolonial option. London: Routledge.

- PICKARD, V. W. \& YANG, G. (2017). Media activism in the digital age. London; New York: Routledge.

- QUIJANO, A. (2007). Coloniality and modernity/rationality. Cultural Studies, 21(2-3), 168-178. doi: 10.1080/09502380601164353.

- SAINI, A. (2019). Superior: The return of race science. London: Harper Collins Publishers.

- TITLEY, G. (2019). Racism and the media. London: SAGE Publications.

- TUCK, E. \& YANG, K. W. (2012). Decolonization is not a metaphor. Decolonization: Indigeneity, Education \& Society, 1(1), 01-40.

- WANG, D. \& SOULE, S. (2012). Social Movement Organizational Collaboration: Networks of Learning and the Diffusion of Protest Tactics, 1960-1995. American Journal of Sociology, 117(6), 1674-1722. doi: 10.1086/664685

- YANCY, G. (2017). On race: 34 conversations in a time of crisis. New York: Oxford University Press. 


\section{Biographies}

\section{Leonardo Custódio}

Åbo Akademi University (Turku, Finland)

ORCID: 0000-0002-7537-9671

leonardo.custodio@abo.fi

Leonardo Custódio is a postdoctoral researcher on Minorities' studies at Åbo Akademi University, Finland. Custódio received his PhD in Social Sciences at Tampere University (2016). His scholarly and activist work has focused on media activism as processes through which people who suffer from inequalities and racism use media for rights, justice, respect and changes. Custódio's book "Favela media activism: Counterpublics for human rights in Brazil" was published in 2017 by Lexington Books. As an activist researcher, Custódio is one of the coordinators, together with Monica Gathuo, of the Anti-Racism Media Activist Alliance. ARMA Alliance is a collaborative anti-racist, activist-research initiative based in Finland. ARMA Alliance is funded by the Kone Foundation (2018-2020).

\section{Monica Gathuo}

University of Helsinki (Finland)

ORCID: 0000-0002-3975-0840

monica.gathuo@helsinki.fi

Monica Gathuo is a community organizer, freelance media producer and a master's student of global politics and communication in University of Helsinki. Gathuo works with the PoC community and furthermore with the Afrofinnish community in Finland. She has produced podcasts, minidocumentary series and texts to discuss the racial inequalities in Finland. Gathuo co-coordinates together with Leonardo Custódio the Anti-Racism Media Activist Alliance, ARMA Alliance, which is a collaborative anti-racist, activist-research initiative based in Finland. Our main focus is on how people who suffer from racism in different societies use media to raise their voices, mobilize support and act collectively against racism. ARMA Alliance is funded by the Kone Foundation (2018-2020). 